\title{
Pengaruh Metode Pembelajaran Inquiry Berbasis Visualisasi Materi Larutan Elektrolit dan Nonelektrolit di Kelas X IPA SMA Negeri 1 Kawangkoan
}

\author{
Reynaldy Assa ${ }^{* a}$, Wilson A. R. Rombanga , Hardin F. Rares ${ }^{a}$ \\ a Pendidikan Kimia, Universitas Negeri Manado, Tondano, 95618, Indonesia
}

\begin{tabular}{l} 
I N F O A R T I K E L \\
\hline Diterima : 19 Agustus 2019 \\
Disetujui : 7 September 2019 \\
\\
\hline Key word: \\
Electrolyte and Nonelectrolyte \\
Solutions, \\
Inquiry Learning Methods, \\
Learning Outcomes. \\
\hline Kata kunci: \\
Hasil Belajar, \\
Larutan Elektrolit dan \\
Nonelektrolit, \\
Metode Pembelajaran Inquiry.
\end{tabular}

*e-mail: reyassa.ra@gmail.com ${ }^{*}$ Telp:

\begin{abstract}
A B STRACT
The purpose of this study is to examine the effect of visualization-based inquiry learning methods on student learning outcomes in electrolyte and non-electrolyte solution material. This research was conducted in Kawangkoan 1 Public High School, in the even semester X IPA students, 2018/2019 academic year. Class X IPA students $1(n=31)$ as the experimental class and class X IPA $2(n=32)$ as the control class. The test used in this study statistical $t$ test with significance level $\alpha=0.05$ with the testing criteriat $t_{t a b l e}$ then $\mathrm{H}_{0}$ is rejected and $\mathrm{H}_{1}$ accepted. The results obtained in this test obtained tcount 5.25> table 1.670. This test is done not to improve student learning outcomes beyond the minimum standard of completeness criteria in school but this testing is only to see the effect of visualization based inquiry learning methods on student learning outcomes. Based on the results obtained it can be concluded that there are differences in student learning outcomes applied with conventional learning models (control class) and visualization based inquiry learning methods (experimental class).
\end{abstract}

\section{A BSTRAK}

Pelaksanaan penelitian ini bertujuan untuk mengkaji pengaruh metode pembelajaran inquiry berbasis visualisasi terhadap hasil belajar siswa pada materi larutan elektrolit dan nonelektrolit. Penelitian ini dilaksanakan di SMA Negeri 1 Kawangkoan, pada siswa kelas X IPA semester genap, tahun akademik 2018/2019. Siswa kelas X IPA 1 ( $n=31)$ sebagai kelas eksperimen dan siswa kelas X IPA 2 ( $n=32$ ) sebagai kelas kontrol. Pengujian dalam penelitian ini digunakan statistik uji $\mathrm{t}$ dengan taraf nyata $\alpha=0,05$ dengan kriteria pengujian thitung $>$ tabel maka $\mathrm{H}_{0}$ ditolak dan $\mathrm{H}_{1}$ diterima. Hasil yang di dapatkan pada pengujian ini diperoleh thitung 5,25 $>$ ttabel 1,670. Berdarkan hasil yang diperoleh dapat disimpulkan bahwa terdapat perbedaan hasil belajar siswa yang diterapkan dengan model pembelajaran konvensional (kelas kontrol) dan metode pembelajaran inquiry berbasis visualisasi (kelas eksperimen).

\section{Pendahuluan}

Belajar kimia dianggap sebagai bagian penting dalam pendidikan disekolah maupun dalam kehidupan sehari-hari karena belajar kimia adalah ilmu yang mempelajari tentang struktur, sifat, dan perubahan materi yang terjadi di alam semesta [1]. Berbagai perhatian besar telah diberikan oleh para peneliti untuk menciptakan pembelajaran kimia yang efektif dan menyenangkan sehingga siswa dapat belajar dengan baik dan dapat meraih hasil belajar yang optimal. Namun pada kenyataannya dalam proses pembelajaran kimia kurang berjalan dengan baik dikarenakan minat dan semangat belajar siswa yang kurang ditingkatkan pada proses pembelajaran kimia. 
Secara umum, ada dua penyelidikan tentang pembelajaran kimia. Pertama, menguji pemahaman siswa dalam pembelajaran kimia. Hal ini menjelaskan bagaimana siswa pada umumnya memberikan pendapat dan ide-ide mereka dalam belajar kimia, atau pemahaman siswa hanya terfokus pada materi pembelajaran kimia tertentu [2]. Beberapa penelitian mencari tahu bagaimana penggambaran animasi atau secara tiga dimensi dapat memfasilitasi pembelajaran kimia siswa disekolah, dimana proses pembelajaran yang menggunakan animasi ini diharapkan bisa membangkitkan minat dan semangat belajar yang juga bisa meningkatkan hasil belajar siswa di sekolah [3]. Hal ini membuat peneliti semakin tertarik untuk mencari tahu bagaimana membuat siswa menyukai belajar kimia [4]. Kedua, memahami dan mencari tahu tingkat pemahaman siswa dalam belajar kimia dengan menggumpulkan bukti dan data-data yang ada, dalam hal ini untuk mengembangkan konsep pembelajaran yang belum ditingkatkan pada proses pembelajaran disekolah atau untuk meningkatkan pembelajaran kimia di sekolah [5].

Arahan di atas menyarankan untuk memperbaiki atau meningkatkan pembelajaran dan penilaian yang dilakukan guru terhadap siswa. Banyak yang fokus untuk memeriksa kurangnya hasil belajar kimia pada siswa tanpa mencari tahu terlebih dahulu apa yang bisa membuat siswa tertarik dalam belajar kimia khususnya pada materi larutan elektrolit dan nonelektrolit, dikarenakan guru sering menggunakan metode ceramah pada proses pembelajaran sehingga siswa hanya sebatas mendengarkan dan memperhatikan pada saat proses pembelajaran berlangsung. Pembelajaran seperti ini dapat membatasi siswa dalam menyalurkan ide dan kreatifitas mereka dalam pembelajaran yang menyebabkan siswa lebih cepat bosan dalam mengikuti proses pembelajaran sehingga dapat menyebabkan hasil belajar siswa menjadi rendah, maka dari itu untuk meningkatkan pemahaman dan ketertarikan siswa pada pembelajaran kimia khususnya pada materi larutan elektrolit dan nonelektrolit, dapat diterapkan dengan penerapan metode pembelajaran inquiry berbasis visualisasi.
Pembelajaran inquiri terbimbing merupakan pendekatan lewat pemberian makna, dimana siswa dibimbing untuk menentukan konsep melalui pemberian masalah, menyusun hipotesis, melakukan percobaan, analisis data dan pengambilan kesimpulan yang jika keterampilan ini dilatih terus menerus secara bertahap bisa meningkatkan kemampuan berpikir siswa [6]. Metode inquiri mengkondisikan pembelajaran yang melatih keterampilan dalam berpendapat, siswa menjadi terlatih untuk mencari dan menemukan konsep melalui kegiatan percobaan [7]. Dengan demikian, metode pembelajaran inquiry adalah salah satu strategi pembelajaran yang memungkinkan para peserta didik mendapatkan jawaban sendiri. Artinya dalam metode pembelajaran inquiri berbasis visualisasi guru meberikan pertanyaan lewat ilustrasi gambaran atau animasi sehingga siswa mulai dilatih untuk mencari tahu lewat pemecahan masalah.

\section{Metode}

Metode penelitian yang digunakan dalam penelitian ini adalah "Posttest-Only control design" yang dapat dilihat pada, Gambar 1

$$
\begin{array}{lll}
\mathbf{R} & \mathbf{X} & \mathbf{O}_{2} \\
\mathbf{R} & & \mathbf{O}_{4}
\end{array}
$$

Gambar 1. Posttest-Only Control Design

Keterangan:

$\mathrm{R}=$ Sampel penelitian dipilih secara

Random

$\mathrm{X}=$ Kelompok pertama diberi perlakuan

$\mathrm{O}_{2}=$ Tes akhir (posttest) pada kelas eksperimen.

$\mathrm{O}_{4}=$ Tes akhir (posttest)

\section{Hasil dan Pembahasan}

Sebelum melakkukan uji hipotesis, dilakukan terlebih dahulu uji homogenitas dan uji normalitas. Data yang digunakan untuk uji homogenitas dan normalitas yaitu nilai ratarata hasil belajar di kelas eksperimen (metode pembelajaran inquiri berbasis visualisasi) dan kelas control. Pengujian ini dilakukan untuk melihat data kenormalan dan keseragaman yang merupakan syarat dari suatu eksperimen terhadap kedua kelas. 
Pengujian Homogenitas

Hasil uji homogenitas diperoleh analisis pengujian kesamaan dua ragam dengan statistik uji $\mathrm{F}$ pada data memberikan nilai fhitung $=1,06$ sedangkan $f_{\text {tabel }}=2,91$. Hal ini menunjukan bahwa $F_{\text {hitung }}<\mathrm{F}_{\text {tabel }}$ atau Fhitung $=$ $1,01<\mathrm{F}_{\text {tabel }}=2,91$. Jadi, dapat disimpulkan bahwa varians dari kedua kelas eksperimen dan kelas kontrol adalah homogen.

\section{Pengujian Normalitas Hasil Belajar}

Dalam pengujian normalitas hasil belajar ini bertujuan untuk mengetahui apakah data yang di dapatkan berdistribusi normal atau tidak. Uji normalitas ini menggunakan uji Liliefors dengan bantuan program MS. Excel dengan taraf signifikan $(\alpha)=0.05$ dengan jumlah sampel kelas kontrol sebanyak 32 siswa, sedangkan jumlah sampel kelas eksperimen berjumlah 31 siswa.

Hasil uji normalitas post-test kelas kontrol dan kelas eksperimen dapat dilihat dari nilai Lhitung dan Ltabel pada Tabel 1

Tabel 1. Hasil Uji Normalitas

\begin{tabular}{|c|c|c|c|}
\hline \multicolumn{4}{|c|}{ Post-test } \\
\hline $\begin{array}{c}\text { dat } \\
\text { a }\end{array}$ & $\begin{array}{c}\text { Kelas } \\
\text { kontrol }\end{array}$ & $\begin{array}{c}\text { Kelas } \\
\text { eksperim } \\
\text { en }\end{array}$ & $\begin{array}{c}\text { kesimpul } \\
\text { an }\end{array}$ \\
\hline $\mathrm{n}$ & 32 & 31 & $\begin{array}{c}\text { Lhitung }< \\
\text { Ltabel }\end{array}$ \\
\hline Lhitu & 0.1034686 & 0.0545223 & Data \\
\hline$n g$ & 62 & 29 & $\begin{array}{c}\text { berdistrib } \\
\text { usi }\end{array}$ \\
\hline Ltabel & 0,886 & 0,886 & normal \\
\hline
\end{tabular}

Dari data pada tabel di atas dapat disimpulkan bahwa nilai hasil post-test kelas kontrol dan eksperimen berdistribusi normal. Syarat data berdistribusi normal yaitu jika Lhitung $<$ Ltabel.

\section{Pengujian Hipotesis}

Pengujian hipotesis ini menggunakan uji t dengan bantuan MS Excel, dari hasil pengujian hipotesis di dapatkan data yang diperlukan untuk perhitungan hipotesis ada pada Tabel 2.
Tabel 2 Data Yang Diperoleh untuk Perhitungan Hipotesis

\begin{tabular}{cc}
\hline $\mathrm{n}_{1}=31$ & $\mathrm{n}_{2}=32$ \\
\hline $\mathrm{S}_{1}=9.38$ & $\mathrm{~S}_{1}=11.45$ \\
\hline $\mathrm{S}_{1}{ }^{2}=88.02$ & $\mathrm{~S}_{2}{ }^{2}=131.31$ \\
\hline $\mathrm{X}_{1}=71.61$ & $\mathrm{X}_{2}=57.78$ \\
\hline
\end{tabular}

Kelas Eksperimen rata-rata skor $=71.61$ simpangan baku $=9.38$ dan varians $=88.02$ sedangkan untuk kelas Kontrol rata-rata skor $=$ 57.78 simpangan baku $=11.45$ dan varians $=$ 131.31

Berdasarkan tabel distribusi $\mathrm{t}$ pada taraf signifikan $\alpha=0,05$ dengan derajat kebebasan $n_{1}$ $+\mathrm{n}_{2}-2(31+32-2=61)$ maka diperoleh tabel senilai 1,670 dan nilai thitung diperoleh 5.25 berdasarkan kriteria pengujian jika ( $\mathrm{t}$ hitung $>\mathrm{t}$ tabel) maka Ho ditolak dan $\mathrm{H}_{1}$ diterima,dengan demikian dapat disimpulkan bahwa terdapat perbedaan hasil belajar siswa yang diterapkan dengan model pembelajaran Konvensional (kelas kontrol) dan Metode pembelajaran inquiry berbasis visualisasi (kelas eksperimen).

\section{Pembahasan}

Dari hasil penelitian ini populasi yang diambil yaitu di SMA Negeri 1 Kawangkoan yang terbagi atas tiga sampel penelitian yaitu Kelas XI IPA 6 sebagai sampel pengujian validitas dan reliabilitas berjumlah 25 siswa, kemudian Kelas X IPA 1 berjumlah 31 siswa sebagai sampel kelas eksperimen, dan Kelas $X$ IPA 2 berjumlah 32 siswa sebagai sampel kelas kontrol. Dalam penelitian ini menggunakan desain post-test only control group design, setelah itu masing-masing kelas eksperimen dan kelas kontrol diberikan tes hasil belajar untuk melihat nilai hasil belajarnya. Tujuan dari penelitian adalah untuk mengetahui pengaruh metode pembelajaran inquiry berbasis visualisasi terhadap hasil belajar siswa pada materi larutan elektrolit dan nonelektrolit di kelas X IPA SMA Negeri 1 Kawangkoan. Berdasarkan data hasil uji yang didapatkan kesimpulan pada uji homogenitas diperoleh nilai fhitung 1,01 dan untuk nilai Ltabel $\alpha=0,05$ diperoleh nilai $\mathrm{F}_{\text {tabel }}=$ 2,90 maka Fhitung $<F_{\text {tabel }}$ sehingga dapat disimpulkan bahwa kelas eksperimen dan kelas 
kontrol homogen, sedangkan pada uji normalitas yang menggunakan uji Liliefors di dapatkan kesimpulan Lhitung $<\mathrm{L}$ tabel maka data yang diperoleh berdistribusi normal, maka dari kedua persyaratan pengujian itu dapat dilakukan uji hipotesis dengan menggunakan uji perbedaan dua rata-rata $(u j i-t)$.

Pengujian hipotesis ini digunakan uji perbedaan dua rata-rata $(u j i-t)$, di dapatkan berdasarkan tabel distribusi $t$ pada taraf signifikan $\alpha=0,05$ dengan derajat kebebasan $n_{1}$ $+\mathrm{n}_{2}-2(31+32-2=61)$ maka diperoleh tabel senilai 1,670 dan nilai thitung diperoleh 5.25 berdasarkan kriteria pengujian jika thitung lebih besar dari tabel ( thitung $>$ ttabel) maka Ho ditolak dan $\mathrm{H}_{1}$ diterima. Dengan demikian dapat disimpulkan bahwa terdapat perbedaan hasil belajar siswa yang diterapkan dengan model pembelajaran Konvensional (kelas kontrol) dan Metode pembelajaran inquiry berbasis visualisasi (kelas eksperimen).

Untuk mengetahui pengaruh dari metode pembelajaran inquiri berbasis visualisasi terhadap hasil belajar siswa pada materi larutan elektrolit dan nonelektrolit pada penelitian ini yaitu dengan melihat nilai rata-rata hasil belajar antara kelas eksperimen yang menggunakan metode pembelajaran inquiri berbasis visualisasi dengan kelas kontrol yang menggunakan metode pembelajaran konvensional. Kemudian nilai hasil rata-rata kelas eksperimen dibandingkan dengan nilai hasil rata-rata kelas kontrol.

Pembelajaran pada kelas kontrol yang menggunakan metode pembelajaran konvensional terjadi secara konvensional dimana guru menjelaskan dengan cara ceramah dan pemberian tugas pada umumnya di kelas, tapi pada pembelajaran konvensional ini masih menggunakan penjelasan dengan penggambaran secara abstrak dimana gambaran yang diberikan hanya di gambar secara manual dipapan tulis kelas, dan pada pembelajaran ini siswa kurang aktif mungkin dikarenakan siswa hanya mendapat penugasan yang membuat siswa terfokus pada penugasan yang diberikan guru. Hal tersebut menjadikan siswa tidak mendapat pemahaman secara mandiri yang mengakibatkan siswa lebih cepat melupakan pembelajaran yang diberikan. Kondisi pembelajaran ini mengakibatkan hasil belajar akhir siswa menjadi tidak optimal.

Rata-rata skor yang diperoleh kelas ekperimen yaitu 71.61 atau bisa dikatakan tidak mencapai nialai KKM sekolah yaitu 8.00, dikarenakan siswa mengalami kesulitan dalam menjawab post test yang diberikan sehingga rata-rata skor yang diperoleh hanya mendapakan 57.78 tetapi skor disini bertujuan untuk melihat perbandingan antara kedua kelas yang dimana rata-rata skor yang diperoleh kelas ekperimen lebih baik dari pada rata-rata skor yang diperoleh kelas kontrol yaitu 45,08, dari data ini dapat dilihat hasil perbedaan tanpa menggunakan tanpa menggunakan metode pembelajaran inquiry berbasis visualisasi. Perbedaan hasil juga dapat dilihat pada nilai simpangan baku kedua kelas yang dimana nilai simpangan baku kelas ekperimen yaitu 9.38 dari data simapangan baku ini dapat dijelaskan bahwa pemahaman siswa yang menggunakan metode pembelajaran inquiry berbasis visualisasi lebih terpusat atau bisa dikatakan pemahaman siswa di kelas ekperimen setelah menggunakan metode pembelajaran inquiry berbasis visualisasi menjadi lebih dimengerti oleh siswa. Sedangkan untuk nilai simpangan baku yang diperoleh kelas kontrol 11.45 yang mana simpangan baku ini dapat di artikan bahwa pemahaman siswa yang menggunakan metode pembelajaran konvensional masih melebar atau bisa dikatakan bahwa pemahaman siswa dikelas control belum sepenuhnya dimengerti oleh siswa, ada siswa yang sudah mengerti dan ada siswa yang belum bisa mengerti pada saat pemberian materi menggunakan metode konvensional.

Penelitian yang menggunakan metode pembelajaran inquiri berbasis visualisasi ini melatih berpikir siswa dengan bantuan ilustrasi gambaran yang membuat imajinasi berpikir siswa menjadi aktif, karena pembelajaran seperti ini membantu siswa dalam memberikan pendapat apa yang mereka lihat dan pahami pada saat proses pembelajaran berlangsung maupun pada saat melakukan percobaan sederhana. Pembelajaran ini juga membantu siswa berpikir kritis, karena siswa mendapat arahan dari gambaran yang diberikan guru, sehingga siswa tidak hanya mendapat penjelasan kata-kata secara abstrak malainkan penggambaran secara langsung, pembelajaran 
ini yang jika dilatih terusmenerus bisa meningkatan pola pikir imajinasi siswa pada materi yang diberikan. Penggunaan metode pembelajaran inquiri yang terjadi pada siswa berlangsung secara multi arah baik itu antara siswa dengan guru ataupun siswa dengan siswa, karena metode inquiri mengkondisikan proses pembelajaran untuk melatih keterampilan dalam meberikan pendapat, siswa dilatih untuk mencari dan menemukan konsep melalui kegiatan percobaan. Melalui kegiatan pembelajaran dengan metode inkuiri, pola berpikir siswa dituntut untuk berpikir kritis karena siswa diajak untuk merumuskan permasalahan, kemudian membuktikan kebenaran konsep melalui percobaan sederhana dan pengamatan sehingga siswa mendapatkan kesimpulan dari permasalahan. Kegiatan belajar dilaksanakan secara bertahap sehingga dapat memperluas pemahaman siswa terhadap suatu materi [7]. Pembelajaran inquiry dimulai dari mengidentifikasi dan merumuskan masalah yang harus menjawab pertanyaan tersebut dengan pembuktikan secara eksperimen sampai memberikan kesimpulan. Melaui pemberian pertanyaan siswa dilatih melakukan observasi terbuka dengan prediksi dan hal ini bisa membuat siswa untuk mengingat dan memahami suatu materi yang dipelajari, serta mampu mengkombinasikan dengan kehidupan seharihari, sehingga lebih mudah untuk menerapakannya kembali. Sebelum menguji hipotesis, siswa dituntut untuk mengidetifikasi sumber yang mendukung, menguji hipotesis dan memberikan kesimpulan, serta mempresentasikannya yang membuat siswa menjadi terlatih [6].

Hasil dari perbandingan yang diperoleh dari niali hasil kelas eksperimen yang menggunakan metode pembelajaran inquiri berbasis visualisasi lebih baik dibandingkan dengan niali hasil kelas kontrol yang menggunakan metode pembelajaran konvensional. Dengan demikian dapat dilihat pengaruh dari metode pembelajaran inquiri berbasis visualisasi terhadap hasil belajar siswa pada materi larutan elektrolit dan nonelektrolit di kelas X IPA SMA Negeri 1 Kawangkoan.

\section{Kesimpulan}

Terdapat berbedaan signifikan rata-rata hasil belajar siswa antara kelas eksperimen dengan kelas kontrol, karena pengaruh dari metode pembelajaran inquiry berbasis visualisasi pada materi larutan elektrolit dan nonelektrolit. Melalui uji $t$ diperoleh tabel senilai 1,670 dan nilai thitung diperoleh 4,52 berdasarkan kriteria pengujian yang dilakukan jika $t$ hitung $>t$ tabel maka $\mathrm{H}_{0}$ ditolak dan $\mathrm{H}_{1}$ diterima. Sehingga dapat diartikan bahwa terdapat pengaruh terhadap hasil belajar siswa yang menggunakan metode pembelajaran inquiry berbasis visualisasi.

\section{Daftar Pustaka}

1. Cheng, M. M.; Gilbert, J. K., Modelling students' visualisation of chemical reaction. International Journal of Science Education 2017, 39, (9), 1173-1193.

2. Andersson, B., Pupils' conceptions of matter and its transformations (age 12-16). 1990.

3. Zhang, Z. H.; Linn, M. C., Can generating representations enhance learning with dynamic visualizations? Journal of research in science teaching 2011, 48, (10), 1177-1198.

4. Robertson, A. D.; Shaffer, P. S., "Combustion always produces carbon dioxide and water": a discussion of university chemistry students' use of rules in place of principles. Chemistry Education Research and Practice 2014, 15, (4), 763-776.

5. Liu, X.; Lesniak, K., Progression in children's understanding of the matter concept from elementary to high school. Journal of Research in Science Teaching: The Official Journal of the National Association for Research in Science Teaching 2006, 43, (3), 320-347.

6. Nurhidayati, S.; Zubaidah, S.; Indriwati, S. E., Pengaruh Metode Inkuiri Terbimbing Terhadap aktivitas Dan Hasil Belajar Biologi Siswa. Jurnal Kependidikan 2015, 14, (3), 285-294.

7. Mbari, M. A.; Yufrinalis, M.; Nona, T., Pengaruh Penggunaan Metode Pembelajaran Inkuiri Terhadap Hasil Belajar Dan Motivasi Siswa. Prisma Sains: Jurnal Pengkajian Ilmu dan Pembelajaran Matematika dan IPA IKIP Mataram 2018, 6, (2), 94-102. 